\title{
HPV-16/18 detection does not affect the prognosis of head and neck squamous cell carcinoma in younger and older patients
}

\author{
LUCIANO MARQUES-SILVA ${ }^{2}$, LUCYANA CONCEIÇÃO FARIAS ${ }^{1}$, CARLOS ALBERTO DE CARVALHO FRAGA $^{1}$, \\ MARCOS VINÍCIUS MACEDO DE OLIVEIRA ${ }^{1}$, CLÁUDIO MARCELO CARDOS ${ }^{3}$, THIAGO FONSECA-SILVA ${ }^{1}$, \\ CAROLINA CAVALIERI GOMES ${ }^{4}$, ALFREDO MAURÍCIO BATISTA DE-PAULA ${ }^{1}$, \\ RICARDO SANTIAGO GOMEZ ${ }^{2}$ and ANDRÉ LUIZ SENA GUIMARÃES ${ }^{1}$
}

\author{
${ }^{1}$ Department of Dentistry, Universidade Estadual de Montes Claros, Montes Claros; ${ }^{2}$ Department of Clinical \\ Surgery and Oral Pathology, School of Dentistry, Universidade Federal de Minas Gerais, Belo Horizonte; \\ ${ }^{3}$ Department of Medicine, Universidade Estadual de Montes Claros, Montes Claros; ${ }^{4}$ Department of Pathology, \\ Institute of Biological Sciences, Universidade Federal de Minas Gerais, Belo Horizonte, Brazil
}

Received November 25, 2011; Accepted January 24, 2012

DOI: $10.3892 / \mathrm{ol} .2012 .588$

\begin{abstract}
Recently, high-risk human papillomavirus (HPV) has emerged as a possible agent associated with head and neck squamous cell carcinoma (HNSCC) in younger patients. Therefore, the purpose of the present study was to assess the effect of age on the distribution of HPV-16/18 in HNSCC, together with the impact of the virus on patient prognosis. A longitudinal prospective study was used adjusted for age, gender, TNM staging, smoking status and alcohol consumption. HPV was detected by PCR with consensus primers. Results showed there was no difference in the frequency of HPV-16/18 positivity when younger patients were compared to the older patients. No association was found among highrisk HPV positivity, gender, smoking habit and anatomical site. High-risk HPV was associated with advanced TNM in bivariate analyses; however, it did not impact on survival. Only TNM staging was associated with risk of mortality. Our study supports the theory that age does not affect the presence of HPV-16/18 in HNSCC and has no impact on patient prognosis. The incidence of HNSCC among patients under the age of 45 years is reportedly on the increase worldwide. The factors associated with HNSCC in younger adults are not well established. Findings of this study indicate that HPV-16/18 may not play a role in HNSCC patients under the age of 45 years.
\end{abstract}

Correspondence to: Professor André Luiz Sena Guimarães, Universidade Estadual de Montes Claros, Hospital Universitário Clemente de Faria, Laboratório de Pesquisa em Saúde, Avenida Cula Mangabeira, 562 Montes Claros, Minas Gerais 39401-001, Brazil

E-mail: andreluizguimaraes@gmail.com

Key words: head and neck cancer, HPV, younger patients, squamous cell carcinoma

\section{Introduction}

Head and neck squamous cell carcinoma (HNSCC) is the sixth most common type of cancer and causes 350,000 cancer mortalities worldwide each year $(1,2)$. HNSCC comprises malignant epithelial neoplasms that arise in the paranasal sinuses, nasal cavity, oral cavity, pharynx and larynx, and generally affects males between the sixth and ninth decades of life following long-term exposure to smoking and alcohol consumption (3). However, an increase in the incidence of head and neck cancer among patients under the age of 45 years has been reported worldwide (4-10). Some studies suggest that in younger patients, HNSCC arises regardless of the classical risk factors $(4-8,10)$. HPV infection has been suggested as a possible etiologic factor for such cases (11-16). HPV was detected in a variety of HNSCCs $(11-15,17)$ and it was suggested to be associated with lesions of potential malignisation in the head and neck $(18,19)$; however, divergent results are found in the literature regarding the role of HPV presence in $\operatorname{HNSCC}(20,21)$.

Taking these facts into consideration, we investigated whether there is any change in the distribution of HPV-16/18 in younger patients compared to older ones. In addition, we assessed the effect of the virus on patient prognosis. To test these hypotheses we performed a longitudinal prospective study.

\section{Patients and methods}

Patients. In total, 75 patients diagnosed with HNSCC recruited from a database of head and neck surgeries that occurred between 1996 and 2007 in Montes Claros, Brazil, were included in the current study (4). Patients younger than 45 years old were selected $(n=25)$. The older patients $(n=50)$ were randomly selected in a proportion of 2:1 adjusted for gender, TNM staging, anatomical site, smoking and alcohol intake. The patients were from the same geographical area and evaluated/treated by the same practitioner. 
Clinical data. The mean age was 42.1 years (SD 3.17; range, 33-45) for younger HNSCC patients and 62.2 years (SD 8.0; range, 49-82) for older HNSCC patients. Skin colour was not used as a physical descriptor since it is a poor predictor of genomic ancestry in Brazil $(22,23)$. The current investigation was approved by the local Ethics Committee. Information on age, gender, tobacco smoking history, alcohol consumption history, medical history, tumour site, TNM clinical staging and survival was obtained from medical files.

All patients were staged according to the UICC TNM classification of malignant tumours (1997) (24). HNSCC lesions were classified according to the primary site as described in the international classification of diseases (ICD-10) for oncology. The anatomical sites reviewed in this study included: i) 28 (37.3\%) mouth and perioral region sites (C00, $\mathrm{C} 01, \mathrm{C} 02, \mathrm{C} 04$, C05, C06.0 and C06.2); ii) 22 (29.3\%) oropharynx (C09-C10) sites; and iii) 25 (23.4\%) hypopharynx-larynx sites (C12, C13 and C32). The sites were classified according to anatomical site (anterior: Oral mucosa, tongue, retromolar trigon, mouth floor, jugal mucosa and gengival; border/posterior: Base tongue, oropharynx and hypopharynx-larynx). The patients had histologically confirmed HNSCC based on the World Health Organisation criteria (WHO, 1997) $(25,26)$. Patients with a diagnosis of carcinoma in situ or multiple head and neck carcinomas were excluded. Ethics approval for this study was obtained from the local ethics committee (468/06).

HPV identification. HPV-DNA sequences were first polymerase chain reaction (PCR)-amplified by L1 (F: 5'-GCM CAGGGWCATAAYAATGG-3' and R: 5'-CGTCCMAAR GGAWACTGATC-3', where, $\mathrm{M}=\mathrm{A}$ or $\mathrm{C}, \mathrm{R}=\mathrm{A}$ or $\mathrm{G}, \mathrm{W}=\mathrm{A}$ or $\mathrm{T}$, $\mathrm{Y}=\mathrm{C}$ or $\mathrm{T}$ ) and then by HPV-16 (F: 5'-AAGGCCAACTA AATGTCA-C-3' and R: 5'-CTGCTT TTATACTAACCGG-3') and HPV-18 (F: 5'-ACCTTAATGAAAAACCACGA-3' and R: 5'-CGTCGTTTAGAGTCGTTC-3'). $\beta$-globin gene primers were used as an internal control. The primer sequences were described by Katiyar et al (27). PCR was performed in a total volume of $25 \mu \mathrm{l}$ containing approximately $100 \mathrm{ng}$ genomic DNA as a template, $0.5 \mu \mathrm{l}$ of each primer $(20 \mathrm{pmol} / \mu \mathrm{l}), 2.5 \mu \mathrm{l}$ dNTP-mix (25 mM of each, Amresco, Ohio, CA, USA), $2.5 \mu 1$ 10X PCR buffer, $1.25 \mu 1$ magnesium chloride $(50 \mathrm{mM})$ and 2.5 units of Platinum Taq DNA polymerase (Invitrogen Life Technologies, Carlsbad, CA, USA) (Fig. 1). Reactions were performed using positive (cultured virus) and negative (PCR without DNA) controls.

Electrophoresis. The PCR products were verified on a $6.5 \%$ polyacrylamide gel that was electrophoresed at a constant voltage of $120 \mathrm{~V}$ for $1.5 \mathrm{~h}$ and stained with silver nitrate. Electrophoresis results were estimated against a 100-bp ladder.

Statistical analysis. The statistical significance of differences between case and control group distributions for HPV positivity was evaluated using Fisher's test or the Chi-squared test. Survival time was calculated from the date of diagnosis to the time of the last follow-up visit or to the time of mortality. Using these criteria, the records of each patient were reviewed from 0 to 2500 days. Mortalities were the result of locoregional and/or metastatic disease. Mortalities that occurred without evidence of recurrence were excluded from analysis. Survival time was
Table I. The distribution of clinical parameters.

\begin{tabular}{lrr}
\hline & \multicolumn{2}{c}{ Frequencies } \\
\cline { 2 - 3 } Clinical parameters & $\mathrm{n}$ & $\%$ \\
\hline Age & & \\
Older & 50 & 66.7 \\
Younger & 25 & 33.3 \\
Gender & & \\
Male & 64 & 85.3 \\
Female & 11 & 14.7 \\
Tobacco habit & & \\
Yes & 72 & 96.0 \\
No & 3 & 4.0 \\
Alcohol habit & & \\
Yes & 70 & 63.3 \\
No & 5 & 12.0 \\
TNM staging & & 88.0 \\
I/II & 9 & \\
III/IV & 66 & 37.3 \\
Lesion site & & 62.7 \\
Anterior & 28 & 10.7 \\
Posterior & 47 & 22.7 \\
Anatomical site & & 37.3 \\
Hypopharynx & 8 & \\
Larynx & 17 & \\
Oropharynx & 22 & \\
Oral cavity & 28 & \\
\hline & & \\
& &
\end{tabular}
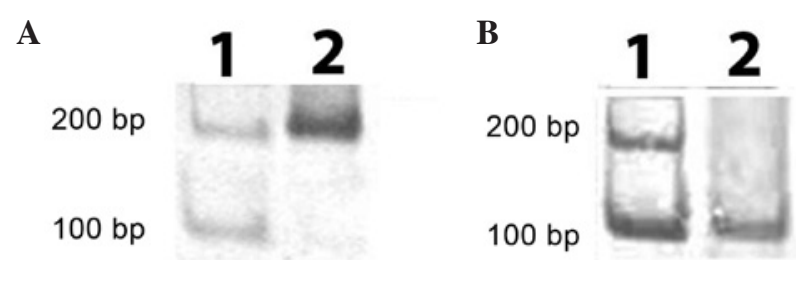

Figure 1. (A) PCR for HPV-16. Lane 1, 100-bp molecular marker. Lane 2, HPV-16-positive (217 bp). (B) PCR for HPV-18. Lane 1, 100-bp molecular marker. Lane 2, HPV-18-positive (100 bp). PCR, polymerase chain reaction; HPV, human papillomavirus.

presented by the means of the Kaplan-Meier method for the variables. Variables were included in the Cox proportional hazards multivariate model. In accordance with the literature, categorical variables considered as references were those associated with a reduced risk of mortality. Analyses were assessed using SPSS 17.0 (SPSS Inc., Chicago, IL, USA), and statistical significance was set at $\mathrm{p}<0.05$.

\section{Results}

The descriptive data of the population used in the current study are shown in Table I. The majority of patients (96\%) in the 
Table II. The distribution of clinical and molecular parameters according to a positive HPV status.

\begin{tabular}{|c|c|c|c|c|c|c|c|c|c|}
\hline & $\begin{array}{c}\text { HPV16- } \\
(\%)\end{array}$ & $\begin{array}{c}\text { HPV16 } 16^{+} \\
(\%)\end{array}$ & P-value & $\begin{array}{c}\text { HPV-18- } \\
(\%)\end{array}$ & $\begin{array}{l}\mathrm{HPV}-18^{+} \\
(\%)\end{array}$ & P-value & $\begin{array}{c}\text { HPV-16/18- } \\
(\%)\end{array}$ & $\begin{array}{c}\mathrm{HPV}-16 / 18^{+} \\
(\%)\end{array}$ & P-value \\
\hline \multicolumn{10}{|l|}{ Age } \\
\hline Older & $38(69.1)$ & $12(60.0)$ & & $26(63.4)$ & $24(70.6)$ & & $19(63.3)$ & $31(68.9)$ & \\
\hline Younger & 17 (30.9) & $8(40.0)$ & 0.318 & 15 (36.6) & $10(29.4)$ & 0.342 & $11(36.7)$ & $14(31.1)$ & 0.399 \\
\hline \multicolumn{10}{|l|}{ Gender } \\
\hline Male & $58(86.6)$ & $6(75)$ & & 34 (82.9) & $30(88.2)$ & & $26(86.7)$ & $38(84.4)$ & \\
\hline Female & $9(13.4)$ & $2(25)$ & 0.333 & $7(17.1)$ & $4(11.8)$ & 0.378 & $4(13.3)$ & 7 (15.6) & 0.533 \\
\hline \multicolumn{10}{|l|}{ Smoking habit } \\
\hline Yes & $54(98.2)$ & $18(90.0)$ & & $39(95.1)$ & $33(97.1)$ & & $29(96.7)$ & 43 (95.6) & \\
\hline No & $1(1.8)$ & $2(10.0)$ & 0.172 & $2(4.9)$ & $1(2.9)$ & 0.464 & $1(3.3)$ & $2(4.4)$ & 0.650 \\
\hline \multicolumn{10}{|l|}{ TNM staging } \\
\hline $\mathrm{I} / \mathrm{II}$ & 7 (12.7) & $2(10.0)$ & & $7(17.1)$ & $2(5.9)$ & & $7(23.3)$ & $2(4.4)$ & \\
\hline III/IV & $48(87.3)$ & $18(90.0)$ & 0.552 & 34 (82.9) & $32(94.1)$ & 0.129 & $23(76.7)$ & 43 (95.6) & 0.018 \\
\hline \multicolumn{10}{|l|}{ Lesion site } \\
\hline Anterior & $20(36.4)$ & $6(30.0)$ & & 15 (36.6) & $11(32.4)$ & & $10(33.3)$ & $16(35.6)$ & \\
\hline Posterior & 35 (63.6) & $14(70.0)$ & 0.411 & $26(63.4)$ & $23(67.6)$ & 0.445 & $20(66.7)$ & $29(64.4)$ & 0.522 \\
\hline \multicolumn{10}{|l|}{ Anatomical site } \\
\hline Hypopharynx & $5(9.1)$ & $3(15)$ & & $2(4.8)$ & $6(18.2)$ & & $2(6.6)$ & $6(13.3)$ & \\
\hline Larynx & $10(18.2)$ & $7(35)$ & & $13(31.0)$ & $4(12.1)$ & & $8(26.7)$ & $9(20.0)$ & \\
\hline Oropharynx & $18(32.7)$ & $4(20)$ & & $10(23.8)$ & $12(36.4)$ & & $8(26.7)$ & $14(31.1)$ & \\
\hline Oral cavity & $22(40.0)$ & $6(30)$ & 0.319 & $17(40.4)$ & $11(33.3)$ & 0.105 & $12(40.0)$ & $16(35.6)$ & 0.725 \\
\hline
\end{tabular}

$\mathrm{HPV}^{+}$, positivity for human papillomavirus; $\mathrm{HPV}^{-}$, absence of human papillomavirus. Bold indicates a statistically significant result.

study population were smokers and consumed alcohol $(93.3 \%)$. Moreover, $88 \%$ presented with advanced TNM staging.

Table II shows the distribution of clinical and molecular parameters according to HPV status. There is no change in the frequency of HPV-16/18 related to patient age. No association was found among high-risk HPV positivity, gender, smoking habit and anatomical site. In combination, high-risk HPV was associated with advanced TNM in bivariate analyses (Table II); however, it did not impact on the survival (Table III). Anatomical site and age did not interfere with the survival. Only TNM staging was associated with risk of mortality (Table III).

\section{Discussion}

Currently, there are no biological mechanisms that could justify the high-risk HPV predilection for a specific anatomical site in the head and neck. The role of high-risk HPV in HNSCC has recently been highlighted in the oropharynx (13), oral cavity (14), larynx $(15)$, hypopharynx $(11,12)$ and in HNSCC metastasis (17). The relevance of the high-risk HPV-E6/E7 protein for the carcinogenesis of multiple head and neck sites was demonstrated in transgenic mice (28-30). In addition, there is no consensus in the literature to detect HPV infection (20). In agreement with these facts, we did not observe high-risk HPV predilection for anatomical sites. The absence of consensus is justified by the differences in the study sample. It
Table III. Cox regression analyses in HNSCC patients with a follow-up of 2,500 days.

\begin{tabular}{|c|c|c|c|c|}
\hline & \multirow[b]{2}{*}{ P-value } & \multirow[b]{2}{*}{ OR } & \multicolumn{2}{|c|}{$95 \% \mathrm{CI}$} \\
\hline & & & Lower & Upper \\
\hline \multicolumn{5}{|l|}{ TNM } \\
\hline I/II & Reference & & & \\
\hline III/IV & 0.015 & 6.052 & 1.423 & 25.742 \\
\hline \multicolumn{5}{|l|}{ Age } \\
\hline Younger & Reference & & & \\
\hline Older & 0.394 & 1.316 & 0.700 & 2.474 \\
\hline \multicolumn{5}{|l|}{ Site } \\
\hline Anterior & Reference & & & \\
\hline Posterior & 0.317 & 0.741 & 0.412 & 1.333 \\
\hline \multicolumn{5}{|l|}{ HPV-16/18 } \\
\hline $\mathrm{HPV}^{-}$ & Reference & & & \\
\hline $\mathrm{HPV}^{+}$ & 0.886 & 0.957 & 0.527 & 1.739 \\
\hline $\begin{array}{l}\text { OR, odds rat } \\
\text { squamous ce } \\
\text { adjusted to th } \\
\text { result. }\end{array}$ & $\begin{array}{l}\text { PV, human pa } \\
\text { cinoma; CI, } \\
\text { t-fit model. }\end{array}$ & $\begin{array}{l}\text { omaviru } \\
\text { nfidence } \\
\text { I indicate }\end{array}$ & $\begin{array}{l}\text { NSCC, h } \\
\text { rval. The } \\
\text { statisticall }\end{array}$ & $\begin{array}{l}\text { and neck } \\
\text { odel was } \\
\text { gnificant }\end{array}$ \\
\hline
\end{tabular}


is well known that there are limitations for paraffin-embedded tissues, particularly as the fixation makes it difficult to purify RNA from paraffin-embedded tissues $(17,31,32)$. Although non-quantitative PCR-based methods do not allow for the determination of infectious activity, these methods are beneficial as they provide greater sensitivity and specificity than in situ hybridisation techniques (20). Evidence suggests that the p16 immunohistochemistry could be used as a survival biomarker in head and neck cancer (33) and aid in high-risk HPV detection (18).

A possible association between HPV infection and the development of HNSCC in younger patients has been proposed (16). In addition, it has been postulated that HPV-positive tumours are a subgroup of HNSCC that is distinct from tobacco- and alcohol-induced carcinomas (19). An absence of $p 16_{C D K N 2 A}$ mutations as well as the expression of p16 is the characteristic feature of high-risk HPV-positive tumours, in contrast to the inactivation of the $p 16_{C D K N 2 A}$ gene in HPV-negative tumours (34). p16 protein is important in the regulation of the $\mathrm{G} 1 / \mathrm{S}$ phase cell-cycle checkpoint $(33,35,36)$ and it has been reported that p16-positive tumours have a better prognosis than p16-negative tumours (33). Therefore, p16 expression may explain the reason for HPV-positive tumours showing a favourable prognosis as compared to HPV-negative tumours. In the current study, HPV-16/18 positivity was not associated with age or survival. The explanation for these findings may be the rigorous selection criteria (age, gender, TNM staging and anatomical site) or that the simultaneous presence of some of these independent variables alters the evolution of cancer in a different way. Moreover, the majority of our patients were smokers, thus our data are in agreement with previous studies (21). Genetic and epigenetic factors are associated with a susceptibility to cancer development at a young age $(4,37)$. Alternatively, genetic and epigenetics factors may play a stronger role than HPV-16/18 infection in the development of HNSSC at an early age (38-42). In the current study, we did not observe differences in survival associated with age, in agreement with previous studies $(4,37)$.

The mechanisms underlying the association between high-risk HPV and HNSCC have been unclear. Studies using SCC samples shed light on the role of high-risk HPV infection in epigenetic regulation (43). For example, it was suggested that HPV-16 induces the methylation of $p 16_{C D K N 2 A}(44)$; however, as oncogenic HPV neutralises phosphorylated Rb (PRb)-mediated control of the cell cycle, there would be no advantage for the HPV-infected host cell to block the same signalling pathway at another checkpoint by downregulating p16 ${ }_{C D N N 2 A}(45-47)$.

In conclusion, our study supports the theory that there is no change in the frequency of HPV-16/18 positivity in younger patients when compared to the older ones. In addition, HPV-16/18 presence did not change the HNSCC prognosis.

\section{Acknowledgements}

This study was supported by grants from Conselho Nacional de Desenvolvimento Científico e Tecnológico (CNPq) and Fundação de Amparo a Pesquisa do Estado de Minas Gerais (FAPEMIG). Dr Guimarães and Dr Gomez are research fellows of CNPq. Dr De Paula is a research fellow of FAPEMIG.

\section{References}

1. Parkin DM: Global cancer statistics in the year 2000. Lancet Oncol 2: 533-543, 2001

2. Parkin DM, Bray F, Ferlay J and Pisani P: Global cancer statistics, 2002. CA Cancer J Clin 55: 74-108, 2005.

3. Argiris A and Eng C: Epidemiology, staging, and screening of head and neck cancer. Cancer Treat Res 114: 15-60, 2003.

4. De Paula AM, Souza LR, Farias LC, et al: Analysis of 724 cases of primary head and neck squamous cell carcinoma (HNSCC) with a focus on young patients and p53 immunolocalization. Oral Oncol 45: 777-782, 2009.

5. Garavello W, Spreafico R and Gaini RM: Oral tongue cancer in young patients: a matched analysis. Oral Oncol 43: 894-897, 2007.

6. Gawecki W, Kostrzewska-Poczekaj M, Gajecka M, Milecki P, Szyfter K and Szyfter W: The role of genetic factor in etiopathogenesis of squamous cell carcinoma of the head and neck in young adults. Eur Arch Otorhinolaryngol 264: 1459-1465, 2007.

7. Llewellyn CD, Johnson NW and Warnakulasuriya S: Factors associated with delay in presentation among younger patients with oral cancer. Oral Surg Oral Med Oral Pathol Oral Radiol Endod 97: 707-713, 2004.

8. Manuel S, Raghavan SK, Pandey M and Sebastian P: Survival in patients under 45 years with squamous cell carcinoma of the oral tongue. Int J Oral Maxillofac Surg 32: 167-173, 2003.

9. Myers JN, Elkins T, Roberts D and Byers RM: Squamous cell carcinoma of the tongue in young adults: increasing incidence and factors that predict treatment outcomes. Otolaryngol Head Neck Surg 122: 44-51, 2000.

10. Siriwardena BS, Tilakaratne A, Amaratunga EA, et al: Analysis of histopathological and immunohistochemical differences of oral squamous cell carcinoma in young and old patients in Sri Lanka. J Oral Pathol Med 36: 357-362, 2007.

11. Baumann JL, Cohen S, Evjen AN, et al: Human papillomavirus in early laryngeal carcinoma. Laryngoscope 119: 1531-1537, 2009.

12. Blomberg M, Nielsen A, Munk C and Kjaer SK: Trends in head and neck cancer incidence in Denmark, 1978-2007: focus on human papillomavirus associated sites. Int J Cancer 129: 733-741, 2011.

13. D'Souza G, Kreimer AR, Viscidi R, et al: Case-control study of human papillomavirus and oropharyngeal cancer. $\mathrm{N}$ Engl J Med 356: 1944-1956, 2007.

14. Saini R, Tang TH, Zain RB, et al: Significant association of high-risk human papillomavirus (HPV) but not of p53 polymorphisms with oral squamous cell carcinomas in Malaysia. J Cancer Res Clin Oncol 137: 311-320, 2011.

15. Torrente MC, Rodrigo JP, Haigentz M Jr, et al: Human papillomavirus infections in laryngeal cancer. Head Neck 33: 581-586, 2011.

16. Zhang ZY, Sdek P, Cao J and Chen WT: Human papillomavirus type 16 and 18 DNA in oral squamous cell carcinoma and normal mucosa. Int J Oral Maxillofac Surg 33: 71-74, 2004.

17. Barwad A, Sood S, Gupta N, Rajwanshi A, Panda N and Srinivasan R: Human papilloma virus associated head and neck cancer: a PCR based study. Diagn Cytopathol: April 6, 2011 (E-pub ahead of print).

18. Angiero F, Gatta LB, Seramondi R, et al: Frequency and role of HPV in the progression of epithelial dysplasia to oral cancer. Anticancer Res 30: 3435-3440, 2010.

19. Hoffmann M, Gorogh T, Gottschlich S, et al: Human papillomaviruses in head and neck cancer: 8 year-survival-analysis of 73 patients. Cancer Lett 218: 199-206, 2005.

20. Marur S, D'Souza G, Westra WH and Forastiere AA: HPV-associated head and neck cancer: a virus-related cancer epidemic. Lancet Oncol 11: 781-789, 2010.

21. Salem A: Dismissing links between HPV and aggressive tongue cancer in young patients. Ann Oncol 21: 13-17, 2010.

22. Parra FC, Amado RC, Lambertucci JR, Rocha J, Antunes CM and Pena SD: Color and genomic ancestry in Brazilians. Proc Natl Acad Sci USA 100: 177-182, 2003.

23. Pimenta JR, Zuccherato LW, Debes AA, et al: Color and genomic ancestry in Brazilians: a study with forensic microsatellites. Hum Hered 62: 190-195, 2006.

24. Sobin LH: TNM: evolution and relation to other prognostic factors. Semin Surg Oncol 21: 3-7, 2003.

25. Broders AC: Squamous-cell epithelioma of the skin: a study of 256 cases. Ann Surg 73: 141-160, 1921. 
26. Bryne M, Nielsen K, Koppang HS and Dabelsteen E: Reproducibility of two malignancy grading systems with reportedly prognostic value for oral cancer patients. J Oral Pathol Med 20: 369-372, 1991.

27. Katiyar S, Hedau S, Jain N, et al: p53 gene mutation and human papillomavirus (HPV) infection in esophageal carcinoma from three different endemic geographic regions of India. Cancer Lett 218: 69-79, 2005.

28. Jabbar S, Strati K, Shin MK, Pitot HC and Lambert PF: Human papillomavirus type 16 E6 and E7 oncoproteins act synergistically to cause head and neck cancer in mice. Virology 407 : 60-67, 2010.

29. Ocadiz-Delgado R, Marroquin-Chavira A, Hernandez-Mote R, et al: Induction of focal epithelial hyperplasia in tongue of young bk6-E6/E7 HPV16 transgenic mice. Transgenic Res 18: 513-527, 2009.

30. Strati K, Pitot HC and Lambert PF: Identification of biomarkers that distinguish human papillomavirus (HPV)-positive versus HPV-negative head and neck cancers in a mouse model. Proc Natl Acad Sci USA 103: 14152-14157, 2006.

31. Coombs NJ, Gough AC and Primrose JN: Optimisation of DNA and RNA extraction from archival formalin-fixed tissue. Nucleic Acids Res 27: e12, 1999.

32. Lehmann U: MicroRNA-profiling in formalin-fixed paraffinembedded specimens. Methods Mol Biol 667: 113-125, 2010

33. Fischer CA, Zlobec I, Green E, et al: Is the improved prognosis of p16 positive oropharyngeal squamous cell carcinoma dependent of the treatment modality? Int J Cancer 126: 1256-1262, 2010.

34. Perez-Ordonez B, Beauchemin M and Jordan RC: Molecular biology of squamous cell carcinoma of the head and neck. J Clin Pathol 59: 445-453, 2006

35. Nakahara Y, Shintani S, Mihara M, Ueyama Y and Matsumura T: High frequency of homozygous deletion and methylation of p16(INK4A) gene in oral squamous cell carcinomas. Cancer Lett 163: 221-228, 2001

36. Reed AL, Califano J, Cairns P, et al: High frequency of p16 (CDKN2/MTS-1/INK4A) inactivation in head and neck squamous cell carcinoma. Cancer Res 56: 3630-3633, 1996.
37. Farias LC, Fraga CA, De Oliveira MV, et al: Effect of age on the association between p16CDKN2A methylation and DNMT3B polymorphism in head and neck carcinoma and patient survival. Int J Oncol 37: 167-176, 2010.

38. Argiris A, Karamouzis MV, Raben D and Ferris RL: Head and neck cancer. Lancet 371: 1695-1709, 2008

39. Diniz MG, Borges ER, Guimaraes AL, et al: PTCH1 isoforms in odontogenic keratocysts. Oral Oncol 45: 291-295, 2009.

40. Gomes CC, Drummond SN, Guimaraes AL, Andrade CI, Mesquita RA and Gomez RS: P21/ WAF1 and cyclin D1 variants and oral squamous cell carcinoma. J Oral Pathol Med 37: 151-156, 2008

41. Liu Z, Wang L, Wang LE, Sturgis EM and Wei Q: Polymorphisms of the DNMT3B gene and risk of squamous cell carcinoma of the head and neck: a case-control study. Cancer Lett 268: 158-165, 2008.

42. Moreira PR, Guimaraes MM, Guimaraes AL, et al: Methylation of P16, P21, P27, RB1 and P53 genes in odontogenic keratocysts. J Oral Pathol Med 38: 99-103, 2009.

43. Wu MF, Cheng YW, Lai JC, et al: Frequent p16INK4a promoter hypermethylation in human papillomavirus-infected female lung cancer in Taiwan. Int J Cancer 113: 440-445, 2005.

44. Lin TS, Lee H, Chen RA, et al: An association of DNMT3b protein expression with P16INK4a promoter hypermethylation in non-smoking female lung cancer with human papillomavirus infection. Cancer Lett 226: 77-84, 2005.

45. Cuschieri K and Wentzensen N: Human papillomavirus mRNA and p16 detection as biomarkers for the improved diagnosis of cervical neoplasia. Cancer Epidemiol Biomarkers Prev 17: 2536-2545, 2008.

46. Munger K, Basile JR, Duensing S, et al: Biological activities and molecular targets of the human papillomavirus E7 oncoprotein. Oncogene 20: 7888-7898, 2001.

47. Nemes JA, Deli L, Nemes Z and Marton IJ: Expression of $\mathrm{p} 16$ (INK4A), $\mathrm{p} 53$, and $\mathrm{Rb}$ proteins are independent from the presence of human papillomavirus genes in oral squamous cell carcinoma. Oral Surg Oral Med Oral Pathol Oral Radiol Endod 102: 344-352, 2006. 